\section{The Solar Corona}

Proceedings of International Astronomical Union Symposium No. 16, held at Cloudoroft, New Moxico, U.S.A., 28-30 August, 1961. Edited by John W. Evans. Pp. xi +344. (New York: Academic Press, Inc.; London: Academic Press, Inc. (London), Ltd., 1963.) 100s.

$\mathrm{T}$ HE thirty papers presented at the Clouderoft symposium, and contained in this volume, provido a comprehensive review of the eonsiderable amount of research on the solar corons which is at present being undertekon. Contributions have been grouped in three sections-"Local Physics of the Corona", "Coronal Phenomena", and "Largor Aspocts of the Corona"-oach of which is introduced by one or two review articles.

The first section, with the introductory paper by C. W. Allen, discusses such topios as the discrepancy in the coronal temperatures obtained by different methods, the ionization and excitation equilibria and coronal line emission, and possible heating mochanisms. Montion should bo made of a paper on "Solar X-Ray Emission" by $H$. Friedman which gives a survey of some improssive results in this wave-length region, obtainod from rocket and sitollito work. The socond section has two reviews, the fast and the slow phenomena being discusscd by J. P. Wild and by M. Waldmeior rospoctivoly. Tho flareassociatod phonomena and the relationship of the corona to prominences receive much attention. There are also two or three interesting papers on obsorvational tochniquos which might have been botter grouped under a separate heading.

The section on the "Larger Aspects of the Corona" deals with quostions of general structure, and with the origin and nature of corpuscular streams. This is probably the aspect of the subject which is most spoculativo st prosont, but which is most likoly to bonefit in the next few years from rocket observations in interplanetary space. The roview for this section was writton by $\mathbf{S}$. Chapman, while E. R. Mustol mado a substantial contribution on the corpuscular streams and their relationship to regions of solar activity. The volume also contrins short reports of nine informal discussions, which are useful in pin-pointing those problems most in nexd of sttention. A further section contains fivo communicatod papers which could not be presented at the symposium for want of time.

During recent years, the study of the solar corons appears to havo entorod a now phase, with new obsorva. tional techniques providing a wealth of information from the X-ray region to the radio wave-lengths. These Proceedings provide ample evidence of the rapid increase which is occurring in our understanding of the corone as a consequenes.

D. J. Faulkner

\section{An Economic Geography of Oil}

By Dr. Poter R. Odoll. (Boll's Advanced Economic Goographios.) Pp. xii +219 . (London: G. Bell and Sons, Ltd., 1963.) 22s. 6d. net.

AVAILABLE literature of the petroleum industry A contains more than avorago roferonces to essential economies. They are chiefly statistical, as they wuuld necessarily be, and as such find a relativoly limitod appeal in the broader sense of the tochnology. The trouble with these books and essays is that they tend to date in a matter of a few yoars aftor publication beonuse, in the oil world particularly, economic circumstances change so rapidly that the mathematics of supply, demand, refining, transport and distribution throughout tho world can never bo rodneod to static formulæ. This book, howevor, is in a rather different category in that the stress is on basic geographical analysis of the activitios of the world oil industry, not so much on purely present-day statistical data and hypothetical trends in the future. Coming from the pen of a locturer in geography at tho London Sohool of
Economics and Political Science, it would be anticipatod that the diseipline of geographical seience applied to the primary commercial factors in the industry would break new and profitable ground. Although the book is designatod as an introductory investigation, partly owing to limitations on space, also becquse of what the author modestly describes as ". . . my own inability to grasp and to bring out oll the rolovant factors which contribute to tho geographical distribution of the production, refining and consumption of oil", there is little doubt that a moro ambitious treatiso on the subjeot would, at this junoture, probably have defeated its objoct.

The book is divided into four parts-(1) the pattern of world oil supply; (2) the pattern of world oil demand; (3) rofinirg, transport and distribution; (4) conolusionconcerned with the oil industry and economic developmont. Part 1 embraces consideration of the industry's rosources, tho world pattern of production and the determ. ining factors thereof. Part 2 discusses the pattern of oil consumption and the fastors influencing this demand. Part 3 describes the pattorn of refining and the determinants of refinery location, also transport and distribution. Part 4 is in itself quite a masterly exposition of the relationship of the industry to the countries within which its activities are at present located. Here the author quotes R. C. Estall and R. O. Buchanan: "Oil does not in general attract major industries to its source of origin ... major industrial concentrations are not a normal ferture of oilfields as they have been of coslfields". The suthor rcoopts this point as valid both in the past and to-day, and he advances good reasons why this should be so.

'Tho book is well written, and not overwhelmod with masses of statistics although well supported with outline maps, tables and diagrams. As an attempt to bring an extromely complex and ramified subject into assimilablo proportions, it deserves praise.

H. B. Milner

\section{Spirit and Man}

An Essay on Being and Value. By Prof. Nathan Rotenstreich. Pp. 257. (The Hague: Martinus Nijhoff, 1963.) 20.75 guildors.

SPIRIT and Man is essentially a study in ethies. The $S$ outlook is contemporary, but with a woll-balanced historical background. Novelty is scarcely to be expected, but the author makes several interesting observations. Examples are: the limitations of calculating machines, the risk of obliterating creativeness and responsibility if systems of Government are too 'paternal', and the dilemma of true freedom in torms of detachment from man's immediate environment. Evidently, some of these questions are of importance to scientists, especially problems relating to team-work in rosoarch, and the delicate balance between policies dictated from outside, and the desire of the individual (somotimos) to follow his own inclinations.

The book is divided into three main parts: (1) dimensions, (2) features and (3) signifioance. In addition, thore is an adoquate index.

Naturally, the reader will expect a decidedly axiological slant, and in this he will not be disappointed. In fact, the writer sums up by declaring his purpose to be to establish man's worthiness as anchored in the fact that he is a subject, and that the value of his being so is not arbitrary, either anthropocentrically or otherwise.

The text, however, is marred by in excessive number of printer's orrors (singulars for plursls, misplaced punetuation, caroless spelling, and so forth). The proof-roading must have been much below the standard usually achieverd by the publishers. In addition, the writer has the tiresome habit of using the phrase "to be sure" far too often, sometimes even twice on the same page. Nevertheless, it is a usoful book in itsolf, and worth careful study.

F. I. G. RAwLINS 